\title{
Uji Coba Proses Pengempukan Daging dengan Ekstrak Daun Pepaya dan Ekstrak Buah Nanas
}

\author{
Antonius Rizki Krisnadi \\ Universitas Bunda Mulia \\ akrisnadi@bundamulia.ac.id
}

\begin{abstract}
This research aims to determine the effectiveness of the role in the process of pressing meat using papaya leaf extract and pineapple as well as the tenderness, aroma and physical quality of meat before processing. This study uses an experimental method to look for the effect of treatment on others under controlled conditions. The results showed that soaking for 45 minutes of meat (P3) caused a change in the tenderness of the meat, the aroma of the uniqueness of the meat after processing changed mixed with the scent of papaya leaves and pineapple. While good physical quality is indicated by soaking with papaya leaf extract and pineapple for 15 minutes, meanwhile, soaking meat for 30 minutes and 45 minutes shows the results of pale and not fresh meat before food processing. Researchers suggest further research on nutrition and water content in meat.
\end{abstract}

Keywords: Papaya leaf extract, Pineapple fruit extract, physical quality of meat, meat picking process, meat aroma, meat texture

\begin{abstract}
Abstrak
Penelitian ini bertujuan untuk mengetahui efektifitas peran dalam proses pengempukan daging dengan menggunakan ekstrak daun papaya dan buah nanas serta tekstur keempukan, aroma khas dan kualitas fisik daging sebelum dilakukan proses pengolahan. Penelitian ini menggunakan metode eksperimen untuk mencari pengaruh perlakuan terhadap yang lain dalam kondisi yang terkendalikan. Sampel penelitian ini sadalah 15 panelis ahli yang menilai hasil perlakuan daging menggunakan metode kategorisasi. Hasil penelitian menunjukkan, bahwa perendaman selama 45 menit daging (P3) menimbulkan perubahan pada tekstur keempukan dari daging, aroma kekhasan daging setelah diolah berubah bercampur dengan aroma daun papaya dan buah nanas. Sedangkan kualitas fisik yang baik ditunjukkan dengan perendaman dengan ekstrak daun papaya dan buah nanas selama 15 menit, sementara itu, perendaman daging selama 30 menit dan 45 menit menunjukkan hasil daging yang pucat dan tidak segar sebelum proses pengolahan makanan. Saran peneliti diadakan penelitian lanjutan mengenai gizi dan kandungan air pada daging.
\end{abstract}

Kata Kunci : Ekstrak daun papaya, ekstrak buah nanas, kualitas fisik dagingdaging, proses pengempukan daging, aroma daging, tekstur dagingada lagi?

\section{Pendahuluan}

\subsection{Latar Belakang}

Daging didefinisikan sebagai urat daging (otot) yang melekat pada kerangka yang menyebabkan tingkat keempukan dari sebuah daging. Keempukan (tenderness) daging dapat diketahui dengan mengukutmengukur tenaga (force) yang digunakan ketika memotong daging. Semakin tinggi tenaga yang digunakan, maka daging itu semakin keras. Hewan yang baru dipotong dagingnya lentur dan lunak, kemudian terjadi perubahan-perubahan sehingga jaringan otot menjadi keras, kaku dan tidak mudah di gerakkan. Proses ini yang disebut dengan istilah rigor mortis. Dalam keadaan rigor, daging menjadi lebih keras dibandingkan dengan sewaktu baru dipotong. Waktu fase rigor mortis pada daging sapi yaitu 10-24 jam penyembelihan 
dikarenakan cadangan energi otot habis atau otot sudah tidak mampu mempergunakan cadangan energi.

Memperbaiki kualitas daging perlu dilakukan pengolahan agar daging sapi mendapatkan tekstur dengan tingkat keempukan yang baikdapat menjadi empuk. Tingkat keempukan daging merupakan salah satu factor yang paling penting bagi kepuasan konsumen. Weir dalam Maiti (2008) kemudahan saat penggigitan, kemudahan daging masuk ke dalam tenggorokan dan jumlah residu tersisa setelah mengunyah. Masyarakat Indonesia umumnya membeli daging segar tanpa proses pelayuan, sehingga daging menjadi keras dan membutuhkan waktu yang lama untuk memasak. Salah satu cara alami untuk mendapatkan kualitas daging yang empuk adalah dengan memanfaatkan enzim proteolitik. Menurut Astawan (2008) bahwa enzim yang terdapat dalam makanan dapat berasal dari bahan mentah atau mikroorganisme yang terdapat pada makanan tersebut.Hasil penelitian terdahulu yaitu Utami (2010) serta hasil penelitian Murtini dan Qomarudin (2003) ini menunjukkan bahwa dalam pengolahan daging lebih sering mengenal menggunakan daun papaya dengan cara membungkus daging sapi serta perlakuan buah nanas hanya dipotong-potong untuk pengolahan daging. Penelitian Moedh (2004) mengungkapkan bahwa penggunaan enzim bromelin papain merupakan factor-faktor yang mempengaruhi tekstur dan kecerahan warna daging pada daging.

Metode yang digunakan dalam penelitian ini berbeda dengan penelitian terdahulu, dimana eksperimen dilakukan dengan cara membungkus atau dipotong-potong saja, namun dengan cara perendaman daging sapi dengan menggunakan ekstrak dari enzim bromeliny ang terdapat pada buah nanas dan enzim papain yang terdapat pada daun papaya. Perbedaan dengan waktu yang berbeda pada proses pengempukan dengan perendaman menggunakan ekstrak daun papaya dan ekstrak buah nanas waktu ang berbeda pada proses pengempukan dengan perendaman menggunakan ekstrak daun papaya dan ekstrak buah nanas, karena menurut Winarno (1992) menyatakan bahwa aktifitas enzim papin dan enzim bromelin akan lebih efektif pada 30 hingga 80 menit sehingga akan mempengaruhi proses perombakan pada struktur jaringan daging. Adapun tujuan dari penelitian ini adalah Untuk mengetahu iefektifitas pengaruh perendaman daging pada ekstrak daun papaya dan ekstrak buah nanas terhadap tingkat keempukan tingkat kekenyalan (tekstur) dan warna daging dan kualiatas fisik daging sebelum dilakukan proses pengolahan.

\section{Metodologi}

\subsection{Jenis Penelitian}

Jenis penelitian ini adalah penelitian kuantitatif dengan metode eksperimen. Penelitian Kuantitatif merupakan penelitian dengan data berupa angka-angka dan analisis menggunakan statistik. Sedangkan metode eksperimen merupakan metode penelitian yang digunakan untuk mencari pengaruh treatment (perlakuan) tertentu terhadap yang lain dalam kondisi yang terkendalikan (Sugiyono, 2010:107).

Metode eksperimen yang penulis gunakan adalah metode true experiment (Sugiyono, 2010:112). Dikatakan true experiment (eksperimen yang betul-betul), karena dalam desain ini peneliti mengontrol semua variabel luar yang mempengaruhi jalannya eksperimen. Sampel pada penelitian eksperimental ini berjumlah 15 panelis ahli.

\subsection{Teknik Pengumpulan DataDesain Penelitian}

Teknik pengumpulan data penelitian ini mendapat perlakuan dilakukan selama 15, 30 dan 45 perendaman dengan menggunakan ekstrak buah nanas dan ekstrak daun papaya selama 15, 30 
dan 45 menit dalam waktu 1 hari. Data yang dikumpulkan dalam variabel meliputi tekstur keempukan, aroma serta kualitas fisik daging.

Dalam penelitian ini melibatkan kelompok kontrol dan perlakuan. Kelompok kontrol dan perlakukan dibedakan menjadi $\mathrm{P}_{0}$ sebagai kontrol tanpa mendapatkan perlakuan apapun. Sedangkan pada variable kontrol $\mathrm{P}_{1}$ mendapatkan perlakuan perendaman selama 15 menit, $\mathrm{P} 2$ mendapatkan perlakuan perendaman selama 30 menit dan $\mathrm{P}_{3}$ mendapatkan perlakuan selama 45 menit. Aspek pengukuran meliputi aspek tekstur daging, yang menggunakan tiga (3) skala likert (empuk, netral dan tidak empuk). Sedangkan aspek aroma khas daging menggunakan tiga (3) skala likert (tidak tajam, sedang, tajam). Sedangkan aspek kualitas fisik panelis hanya memilih kualitas fisik daging yang terbaik dari setiap perlakuan.

Untuk membuat kategorisasi diperlukan mean teoritik dan satuan standar deviasi populasi. Standar deviasi dihitung dengan cara mencari rentang skor, yaitu skor maksimal yang mungkin diperoleh responden dikurangi dengan skor minimal yang mungkin diperoleh responden dikurangi dengan skor minimal yang mungkin diperoleh responden, kemudian rentang skor tersebut dibagi enam (Azwar, 2012:147). Rumus yang digunakan untuk membuat kategorisasi dalam penelitian ini adalah:

Skor Maksimal Instrumen = Jumlah responden x skor skala terbesar

Skor Minimal Instrumen = Jumlah responden $x$ skor skala terkecil

Mean teoritk $(\mu) \quad=1 / 2$ Skor $($ Maksimal + Skor Minimal $)$

Standar Deviasi Populasi $(\delta) \quad=1 / 6$ (skor maksimal - Skor Minimal)

Berdasarkan perhitungan di atas, dibagi dalam empat kategori:

Tabel 1. Rumus Empat KategoriTabel 1. RUmus Empat Kategori

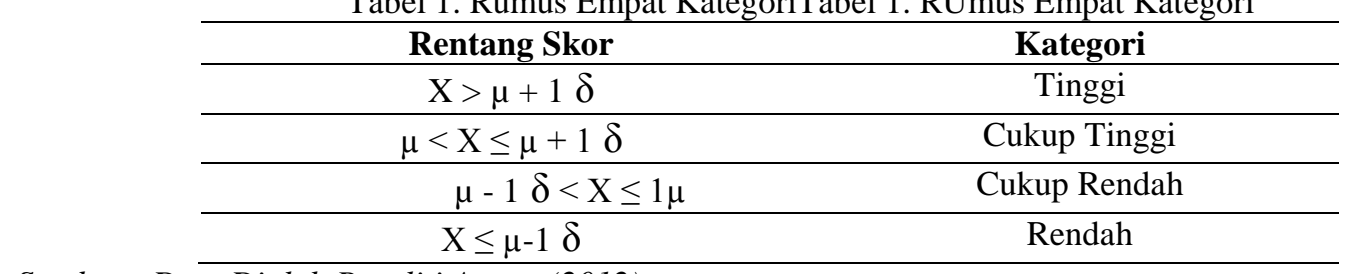

Sumber : Data Diolah Peneliti Azwar(2012)

Keterangan :

$\mathrm{X}=$ skor total

$\mu=$ Mean Teoritik

$\delta=$ Standar Deviasi Populasi

Pada tabel diatas terdapat rumus dalam menentukan empat kategori. Kategori dalam tabel tersebut digunakan dalam menjawab hasil dari jawaban panelis. Perhitungan berdasarkan tabel diatas terdiri dari tinggi, cukup tinggi, cukup rendah dan rendah, yang berarti bahwa tingkat efektifitas yang terjadi dapat dilihat dari empat kategori yang berada pada tabeldiatas.

\section{Hasil dan Pembahasasan}

\subsection{Sifat sensori proses perendaman daging}

Kategorisasi pada perendaman dengan ekstrak daun pepaya dan ekstrak buah nanas pada tekstur daging adalah sebagai berikut:

Skor maksimal $=15 \times 3=45$

Skor Minimal $=15 \times 1=15$

$\mu$

$$
\begin{aligned}
& =1 / 2(\text { skor maksimal }+ \text { skor minimal }) \\
& =1 / 2(45+15) \\
& =30
\end{aligned}
$$


$\delta$

$$
\begin{aligned}
& =1 / 6(\text { skor maksimal }- \text { skor minimal }) \\
& =1 / 6(45-15) \\
& =1 / 6(30) \\
& =5
\end{aligned}
$$

Berdasarkan kategori diatas maka kategori untuk perendaman dengan ekstrak daun pepaya dan ekstrak buah nanas pada tekstur daging adalah :

Tabel 2. Hasil Kategorisasi Tabel 2. Hasil Kategorisasi

\begin{tabular}{ccc}
\hline Rentang Skor & Kategori \\
\hline $\mathrm{X}>35$ & Tinggi \\
\hline $30<\mathrm{X} \leq 35$ & Cukup Tinggi \\
\hline $25<\mathrm{X} \leq 30$ & Cukup Rendah \\
\hline $\mathrm{X} \leq 25$ & Rendah \\
\hline
\end{tabular}

Sumber : Data Diolah Peneliti

Pada tabel 2 merupakan hasil perhtitungan untuk menentukan hasil kategorisasi. Hasil kategorisasi ini yang akan menjadi jawaban dalam penelitian ini dalam menentukan efektifitas perendaman dengan menggunakan ekstrak buah nanas dan daun papaya dilihat dari aspek tektur daging dan aroma dengan konsentrasi dari masing-masing bahan.

Tabel 3. Hasil Analisis Proses Perendaman

\begin{tabular}{lcccc}
\hline \multicolumn{5}{c}{$\begin{array}{l}\text { Proses perendaman dengan Ekstrak Buah } \\
\text { Nekstur }\end{array}$} \\
\hline Sampel & Po & $\mathrm{P}_{1}$ & $\mathrm{P}_{2}$ & $\mathrm{P}_{3}$ \\
\hline Skor Total $(\mathrm{X})$ & 15 & 27 & 33 & 45 \\
\hline
\end{tabular}

Sumber : Data Diolah Peneliti

Berdasarkan kategorisasi berdasarkan hasil penelitian dan perhitungan dari total skor dengan penilaian dari 15 panelis serta perhitungan kategorisasi dapat dilihat pada tabel 3 yaitu, adalah:

Po adalah daging yang tidak mendapatkan perlakuan apa-apa pada proses perendaman berdasarkan hasil dari jawaban panelis dengan total skor adalah 15. Berdasarkan rentang skor yang didapat yang tertera pada tabel 3 masuk kedalam kategori rendah $(\mathrm{X} \leq 25)$ atau tidak menimbulkan perubahan dari segi tekstur keempukan daging dikarenakan Po tidak mendapatkan perlakuan apa-apa dan menjadi variable kontrol. Sedangkan

P1 adalah daging dengan mendapatkan perlakuan proses perendaman selama 15 menit dengan menggunakan ekstrak buah nanas, berdasarkan hasil dari jawaban panelis seperti yang tertera pada tabel 3 dengan total skor 27. Berdasarkan rentang skor yang didapat masuk kedalam kategori cukup rendah $(25<\mathrm{X} \leq 30)$ dalam menimbulkan perubahan dari segi tekstur keempukan daging. Berdasarkan komentar dari panelis memberikan perubahan tekstur sedikit pada tekstur keempukan daging setelah diolah. Berdasarkan hasil penelitian

P2 adalah daging dengan mendapatkan perlakuan proses perendaman selama 30 menit dengan menggunakan ekstrak buah nanas, berdasarkan hasil dari jawaban panelis dengan total skor 33. Berdasarkan rentang skor yang didapat masuk kedalam kategori cukup tinggi $(30<\mathrm{X} \leq$ 35) dalam menimbulkan perubahan dari segi tekstur keempukan daging setelah dilakukan pengolahan. Sedangkan

P3 adalah daging dengan mendapatkan perlakuan proses perendaman selama 45 menit dengan menggunakan ekstrak buah nanas, berdasarkan hasil dari jawaban panelis dengan total 
skor 45. Berdasarkan rentang skor yang didapat masuk kedalam kategori tinggi $(\mathrm{X}>35)$ dalam menimbulkan perubahan dari segi tekstur keempukan daging setelah dilakukan pengolahan.

Analisis hasil penelitian diatas menunjukan bahwa daging yang mendapat perlakuan perendaman 45 menit menimbulkan perubahan dari tekstur keempukan daging. Menurut anam (2003) enzim bromelin yang terdapat pada buah nanas dapat mengurai kandungan protein dan mencerna jaringan otot yang terkandung dalam daging dan semakin lama dalam melakukan proses perendaman maka jaringan ikat protein memberikan efek empuk pada daging.

Tabel 6. Hasil panelis perendaman dengan Ekstrak Buah Nanas pada Aroma daging

Tabel 4. Hasil perendaman Ekstrak Buah Nanas

\begin{tabular}{|c|c|c|c|c|}
\hline \multirow[b]{2}{*}{ Aroma } & \multicolumn{4}{|c|}{$\begin{array}{l}\text { Proses perendaman dengan Ekstrak Buah Nanas pada Tekstur } \\
\text { DagingProses Perendaman Ekstrak Buah Nanas Pada Aroma Daging }\end{array}$} \\
\hline & & & & \\
\hline Sampel & Po & P1 & P2 & P3 \\
\hline Skor Total & 15 & 18 & 22 & 42 \\
\hline
\end{tabular}

Berdasarkan kategorisasi pada tabel 4 berdasarkan hasil penelitian dan perhitungan dari total skor dengan penilaian dari 15 panelis serta perhitungan kategorisasi adalah sebagai berikut.

$\mathrm{P}_{\mathrm{o}}$ adalah daging yang tidak mendapatkan perlakuan apa-apa pada proses perendama berdasarkan hasil dari jawaban panelis dengan total skor adalah 15. Berdasarkan rentang skor yang didapat masuk kedalam kategori rendah $(X \leq 25)$ atau tidak menimbulkan perubahan aroma.

$\mathrm{P}_{1}$ adalah daging dengan mendapatkan perlakuan proses perendaman selama 15 menit dengan menggunakan ekstrak buah nanas, berdasarkan hasil dari jawaban panelis dapat dilihat di tabel 4 dengan total skor 18. Berdasarkan rentang skor yang didapat masuk kedalam kategori rendah $(X \leq 25)$ tidak menimbulkan perubahan aroma dalam kekhasan aroma daging.

$\mathrm{P}_{2}$ adalah daging dengan mendapatkan perlakuan proses perendaman selama 30 menit dengan menggunakan ekstrak buah nanas, berdasarkan hasil dari jawaban panelis dengan total skor 22. Berdasarkan rentang skor yang didapat masuk kedalam kedalam kategori rendah ( $\mathrm{X} \leq$ 25) tidak menimbulkan perubahan aroma dalam kekhasan aroma daging.

$\mathrm{P}_{3}$ adalah daging dengan mendapatkan perlakuan proses perendaman selama 45 menit dengan menggunakan ekstrak buah nanas, berdasarkan hasil dari jawaban panelis dengan total skor 42. Berdasarkan rentang skor yang didapat masuk kedalam kategori tinggi $(\mathrm{X}>35)$ karena merubah aroma kekhasan dari aroma daging setelah proses pengolahan namun dapat ditolerir..

Hasil penelitian diatas dapat dilihat bahwa perlakuan daging pada proses perendaman selama 15 menit dan 30 menit memberikan pengaruh yang rendah, sedangkan pada perlakuan proses perendaman selama 45 menit dapat merubah aroma kekhasan dari daging namun masih dapat diterima oleh panelis. Menurut Lewrie (2003) enzim bromelin yang terdapat pada buah nanas dapat mempertahankan mutu dari daging. 
Tabel 5. Hasil panelis perendaman dengan Ekstrak Daun Papaya pada Tekstur daging

\begin{tabular}{lllll}
\hline \multicolumn{5}{c}{$\begin{array}{l}\text { Proses Perendaman Daging Dengan Ekstrak Daun Pepaya Pada Tekstur } \\
\text { Daging }\end{array}$} \\
Tekstur & Po & P1 & P2 & P3 \\
\hline Sampel & 15 & 23 & 35 & 45 \\
\hline Skor Total (X) & & &
\end{tabular}

Sumber: Data diolah peneliti

Kategorisasi berdasarkan hasil perhitungan dari total skor dengan penilaian dari 15 panelis serta perhitungan kategorisasi yang berada pada tabel 5 adalah sebagai berikut.

Po kontrol daging yang tidak mendapatkan perlakuan apa-apa pada proses perendaman berdasarkan hasil dari jawaban panelis diperoleh total skor adalah 15. Berdasarkan rentang skor yang didapat masuk kedalam kategori rendah $(\mathrm{X} \leq 25)$ atau tidak menimbulkan perubahan dari segi tekstur keempukan daging. Sedangkan $\mathrm{P}_{1}$. daging dengan mendapatkan perlakuan proses perendaman selama 15 menit dengan menggunakan ekstrak daun pepaya, berdasarkan hasil dari jawaban panelis diperoleh total skor 23. $\mathrm{P}_{2}$, daging dengan mendapatkan perlakuan proses perendaman selama 30 menit dengan menggunakan ekstrak daun pepaya, berdasarkan hasil dari jawaban panelis dengan total skor 35. Berdasarkan rentang skor yang didapat masuk kedalam kategori cukup tinggi $(30<\mathrm{X} \leq 35)$ dalam menimbulkan perubahan dari segi tekstur keempukan daging. Sedangkan P3, daging dengan mendapatkan perlakuan proses perendaman selama 45 menit dengan menggunakan ekstrak daun pepaya, berdasarkan hasil dari jawaban panelis diperoleh total skor 45. Berdasarkan rentang skor yang didapat masuk kedalam kategori tinggi (X $\leq 235$ ) dalam menimbulkan perubahan dari segi tekstur keempukan daging namun terlihat beberapa bagian dari daging terurai..

Hasil analisis penelitian diatas didapat bahwa proses perendaman selama 15 menit memberikan pengaruh rendah pada tekstur daging. Sedangkan pada proses perlakuan perendaman selama 30 menit mempunyai pengaruh cukup tinggi. Sedangkan pada proses perlakuan perendaman selama 45 menit mempunyai pengaruh sangat tinggi. Berdasarkan kesimpulan dari panelis proses perendaman selama 30 menit memberikan hasil yang maksimal karena tidak mengurai daging. Hal ini berarti semakin lama proses perendaman dapat menghancurkan tekstur dari daging. Lewrie (2003) menyatakan bahwa cara kerja enzim papain dapat menyebabkan hilangnya ikatan antar serat daging dan pemecahan serat fragmen yang lebih pendek sehingga dapat menurunkan dan mengurai dengan cepat serat-serat dalam zat pengikat.

Hasil analisis dari penelitian diatas adalah pada proses perendaman selama 15 menit dan 30 menit memberikan pengaruh rendah pada aroma kekhasan daging. Sedangkan pada proses perendaman selama 45 menit memberikan pengaruh yang tinggi dan aroma daun papaya yang kuat.

Tabel 6. Kualitas Fisik Daging dengan Perendaman Ekstrak Daun Pepaya dan Ekstrak Buah Nanas

\begin{tabular}{|c|c|c|c|c|c|c|c|c|c|}
\hline \multirow[t]{3}{*}{ Panelis } & Perlakuan & \multicolumn{4}{|c|}{ Ekstrak Daun Pepaya } & \multicolumn{4}{|c|}{ Ekstrak Buah Nanas } \\
\hline & (lama waktu & Daging & Daging & Daging & Daging & Daging & Daging & Daging & Daging \\
\hline & Perendaman) & $\mathrm{I}$ & II & III & IV & I & II & III & IV \\
\hline \multirow[t]{2}{*}{1} & $\mathrm{P}_{0}(($ kontrol $)$ & & & & & & & & \\
\hline & $\mathrm{P}_{1}$ (15 Menit) & & $\sqrt{ }$ & & & & $\sqrt{ }$ & & \\
\hline
\end{tabular}




\begin{tabular}{|c|c|c|c|c|c|c|c|c|c|}
\hline & $\mathrm{P}_{2}$ (30 Menit) & & & & & & & & \\
\hline & $\mathrm{P}_{3}$ (45 Menit) & & & & & & & & \\
\hline \multirow[t]{7}{*}{2} & Perlakuan & \multicolumn{4}{|c|}{ Ekstrak Daun Pepaya } & \multicolumn{4}{|c|}{ Ekstrak Buah Nanas } \\
\hline & (lama waktu & Daging & Daging & Daging & Daging & Daging & Daging & Daging & Daging \\
\hline & Perendaman) & I & II & III & IV & I & II & III & IV \\
\hline & $\mathrm{P}_{0} \quad(($ kontrol $)$ & & & & & & & & \\
\hline & $P_{1}$ (15 Menit) & & $\sqrt{ }$ & & & & $\sqrt{ }$ & & \\
\hline & $\mathrm{P}_{2}$ (30 Menit) & & & & & & & & \\
\hline & $\mathrm{P}_{3}$ (45 Menit) & & & & & & & & \\
\hline \multirow[t]{7}{*}{3} & Perlakuan & \multicolumn{4}{|c|}{ Ekstrak Daun Pepaya } & \multicolumn{4}{|c|}{ Ekstrak Buah Nanas } \\
\hline & (lama waktu & Daging & Daging & Daging & Daging & Daging & Daging & Daging & Daging \\
\hline & Perendaman) & I & II & III & IV & I & II & III & IV \\
\hline & $\mathrm{P}_{0}(($ kontrol $)$ & & & & & & & & \\
\hline & $\mathrm{P}_{1}$ (15 Menit) & & $\sqrt{ }$ & & & & $\sqrt{ }$ & & \\
\hline & $\mathrm{P}_{2}$ (30 Menit) & & & & & & & & \\
\hline & $\mathrm{P}_{3}$ (45 Menit) & & & & & & & & \\
\hline \multirow[t]{7}{*}{4} & Perlakuan & \multicolumn{4}{|c|}{ Ekstrak Daun Pepaya } & \multicolumn{4}{|c|}{ Ekstrak Buah Nanas } \\
\hline & (lama waktu & Daging & Daging & Daging & Daging & Daging & Daging & Daging & Daging \\
\hline & Perendaman) & I & II & III & IV & I & II & III & IV \\
\hline & $\mathrm{P}_{0}(($ kontrol $)$ & & & & & & & & \\
\hline & $\mathrm{P}_{1}$ (15 Menit) & & $\sqrt{ }$ & & & & $\sqrt{ }$ & & \\
\hline & $\mathrm{P}_{2}$ (30 Menit) & & & & & & & & \\
\hline & $\mathrm{P}_{3}$ (45 Menit) & & & & & & & & \\
\hline \multirow[t]{7}{*}{5} & Perlakuan & \multicolumn{4}{|c|}{ Ekstrak Daun Pepaya } & \multicolumn{4}{|c|}{ Ekstrak Buah Nanas } \\
\hline & (lama waktu & Daging & Daging & Daging & Daging & Daging & Daging & Daging & Daging \\
\hline & Perendaman) & I & II & III & IV & I & II & III & IV \\
\hline & $\mathrm{P}_{0}(($ kontrol $)$ & & & & & & & & \\
\hline & $\mathrm{P}_{1}$ (15 Menit) & & $\sqrt{ }$ & & & & $\sqrt{ }$ & & \\
\hline & $\mathrm{P}_{2}$ (30 Menit) & & & & & & & & \\
\hline & $\mathrm{P}_{3}$ (45 Menit) & & & & & & & & \\
\hline \multirow[t]{7}{*}{6} & Perlakuan & \multicolumn{4}{|c|}{ Ekstrak Daun Pepaya } & \multicolumn{4}{|c|}{ Ekstrak Buah Nanas } \\
\hline & (lama waktu & Daging & Daging & Daging & Daging & Daging & Daging & Daging & Daging \\
\hline & Perendaman) & I & II & III & IV & I & II & III & IV \\
\hline & $\mathrm{P}_{0}(($ kontrol $)$ & & & & & & & & \\
\hline & $\mathrm{P}_{1}$ (15 Menit) & & $\sqrt{ }$ & & & & $\sqrt{ }$ & & \\
\hline & $\mathrm{P}_{2}$ (30 Menit) & & & & & & & & \\
\hline & $\mathrm{P}_{3}$ (45 Menit) & & & & & & & & \\
\hline \multirow[t]{5}{*}{7} & Perlakuan & \multicolumn{4}{|c|}{ Ekstrak Daun Pepaya } & \multicolumn{4}{|c|}{ Ekstrak Buah Nanas } \\
\hline & (lama waktu & Daging & Daging & Daging & Daging & Daging & Daging & Daging & Daging \\
\hline & Perendaman) & I & II & III & IV & I & II & III & IV \\
\hline & $\mathrm{P}_{0}(($ kontrol $)$ & & & & & & & & \\
\hline & $\mathrm{P}_{1}$ (15 Menit) & & $\sqrt{ }$ & & & & $\sqrt{ }$ & & \\
\hline
\end{tabular}




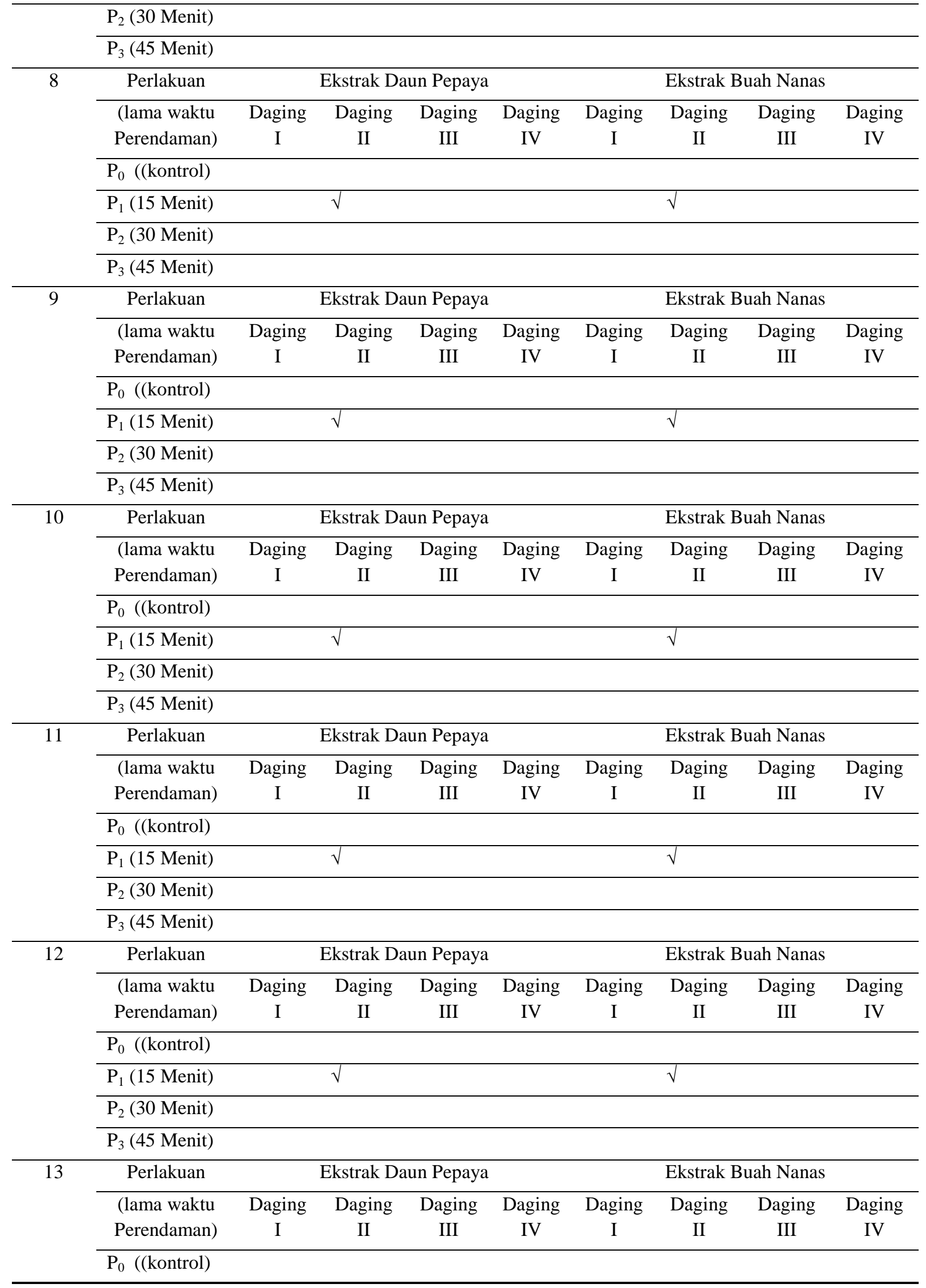




\begin{tabular}{|c|c|c|c|c|c|c|c|c|c|}
\hline & $\mathrm{P}_{1}$ (15 Menit) & \multicolumn{4}{|c|}{$\sqrt{ }$} & \multicolumn{3}{|c|}{$\sqrt{ }$} & \\
\hline & \multicolumn{9}{|l|}{$\mathrm{P}_{2}(30$ Menit $)$} \\
\hline & \multicolumn{9}{|l|}{$\mathrm{P}_{3}$ (45 Menit) } \\
\hline \multirow[t]{6}{*}{14} & Perlakuan & \multicolumn{4}{|c|}{ Ekstrak Daun Pepaya } & \multicolumn{4}{|c|}{ Ekstrak Buah Nanas } \\
\hline & $\begin{array}{l}\text { (lama waktu } \\
\text { Perendaman) }\end{array}$ & $\begin{array}{c}\text { Daging } \\
\text { I }\end{array}$ & $\begin{array}{c}\text { Daging } \\
\text { II }\end{array}$ & $\begin{array}{c}\text { Daging } \\
\text { III }\end{array}$ & $\begin{array}{c}\text { Daging } \\
\text { IV }\end{array}$ & $\begin{array}{c}\text { Daging } \\
\text { I }\end{array}$ & $\begin{array}{c}\text { Daging } \\
\text { II }\end{array}$ & $\begin{array}{c}\text { Daging } \\
\text { III }\end{array}$ & $\begin{array}{c}\text { Daging } \\
\text { IV }\end{array}$ \\
\hline & $\mathrm{P}_{0}(($ kontrol $)$ & & & & & & & & \\
\hline & $\mathrm{P}_{1}$ (15 Menit) & & $\sqrt{ }$ & & & & $\sqrt{ }$ & & \\
\hline & $\mathrm{P}_{2}$ (30 Menit) & & & & & & & & \\
\hline & $\mathrm{P}_{3}$ (45 Menit) & & & & & & & & \\
\hline \multirow[t]{6}{*}{15} & Perlakuan & \multicolumn{4}{|c|}{ Ekstrak Daun Pepaya } & \multicolumn{4}{|c|}{ Ekstrak Buah Nanas } \\
\hline & $\begin{array}{l}\text { (lama waktu } \\
\text { Perendaman) }\end{array}$ & $\begin{array}{c}\text { Daging } \\
\text { I }\end{array}$ & $\begin{array}{c}\text { Daging } \\
\text { II }\end{array}$ & $\begin{array}{c}\text { Daging } \\
\text { III }\end{array}$ & $\begin{array}{l}\text { Daging } \\
\text { IV }\end{array}$ & $\begin{array}{l}\text { Daging } \\
\text { I }\end{array}$ & $\begin{array}{c}\text { Daging } \\
\text { II }\end{array}$ & $\begin{array}{c}\text { Daging } \\
\text { III }\end{array}$ & $\begin{array}{c}\text { Daging } \\
\text { IV }\end{array}$ \\
\hline & $\mathrm{P}_{0}$ ((kontrol) & & & & & & & & \\
\hline & $\mathrm{P}_{1}$ (15 Menit) & & $\sqrt{ }$ & & & & $\sqrt{ }$ & & \\
\hline & $\mathrm{P}_{2}$ (30 Menit) & & & & & & & & \\
\hline & $\mathrm{P}_{3}$ (45 Menit) & & & & & & & & \\
\hline
\end{tabular}

Sumber : Data Diolah Peneliti

Berdasarkan hasil dari panelis sensori kualitas fisik daging setelah direndam dan dibersihkan dengan menggunakan air bersih dan sebelum dilakukan proses pengolahan makanan. Seluruh panelis berpendapat bahwa proses perendaman dengan menggunakan ekstrak buah nanas dan ekstrak daun pepaya pada P1 yaitu proses perendaman selama 15 menit, tidak mempengaruhi kualitas daging seperti Po Kontrol yang tidak mendapatkan perlakuan apapun. Sedangkan P2 pada proses perendaman daging dengan menggunakan ekstrak buah nanas dan ekstrak daun pepaya terlihat lebih pucat dibandingkan dengan Po sebagai kontrol dan P1. Pada proses perendaman P3 yaitu selama 45 menit terlihat sangat pucat dan tidak segar.

\section{Kesimpulan}

Berdasarkan hasil penelitian yang berjudul "Uji Coba Proses Pengempukan Daging dengan Menggunakan Ekstrak Daun Pepaya dan Ekstrak Buah Nanas” didapat kesimpulan bahwa:

1. Proses pengempukan daging dengan menggunakan Ekstrak Daun Pepaya dan Ekstrak Buah Nanas yang memiliki hasil yang baik menurut panelis dilihat dari tekstur keempukan adalah P2 dan P3 yaitu perlakuan proses perendaman selama 30 menit dan 45 menit. Secara penilaian kategorisasi tingkat keempukan P3 dengan menggunakan ekstrak Buah Nanas dan ekstrak daun papaya memiliki hasil tekstur dengan tingkat keempukan yang lebih baik dan memberikan pengaruh pada tekstur keempukan daging setelah diolah,

2. Proses pengempukan daging dengan menggunakan Ekstrak Daun Pepaya dan Ekstrak Buah Nanas memiliki hasil yang baik menurut panelis dilihat dari aroma kekhasan daging adalah P2 dan P3 yaitu perlakuan proses perendaman selama 15menit dan 45 menit. Secara penilaian aroma kekhasan daging P1 dan P2 dengan menggunakan ekstrak buah nanas dan ekstrak daun papaya memiliki nilai kategorisasi yang cukup tinggi namun tidak jauh berbeda dan masih dapat ditolerir.

3. Proses pengempukan daging dengan menggunakan Ekstrak Daun Pepaya dan Ekstrak Buah Nanas memiliki hasil yang baik menurut panelis dilihat dari Kualitas Fisik adalah P1 
dengan perendaman selama 15 menit. Secara penilaian oleh panelis perendaman daging dengan menggunakan ekstrak buah nanas dan ekstrak daun pepaya memiliki kualitas daging yang lebih baik dibandingkan dengan perlakuan P2 dan P3 yang terlihat lebih pucat pada permukaan daging sebelum diolah.

\section{Saran}

Berdasarkan hasil penelitian diatas, dilihat dari keterbatasan waktu dalam peneliti maka:

1. Perlu diadakan penelitian lebih lanjut mengenai kandungan gizi dan protein sesuai dengan proses pengempukan daging dengan menggunakan bahan tersebut.

2. Perlu diadakan penelitian lebih lanjut mengenai kandungan air yang terdapat pada daging setelah dilakukan proses pengolahan pada makanan.

\section{Ucapan Terimakasih}

Penelitian ini mendapatkan bantuan dari Universitas Bunda Mulia khususnya kepada Program Studi Pariwisata Universitas Bunda Mulia, serta para panelis-panelis dan dosen yang membantu saya dalam penyelesaiin penelitian ini. Ucapan terimakasih untuk Jurnal Sosial Humaniora dan Pendidikan Politeknik Balikpapan atas kesempatan dalam penerbitan jurnal dalam penelitian ini. Terimakasih atas para editor yang membantu dalam perbaikan jurnal ini sehingga jurnal ini dapat lebih baik.

\section{Daftar Pustaka}

Astawan, Made.2008.Sehat dengan hidangan hewani.Jakarta: Penebar Swadaya.Budiman, J., \& Susanty, Y. F. (2014). Analisis Komparatif Penerapan Suku Bunga KPR Bank Batam. Jurnal Manajemen, 14(1), 97-124. Retrieved from http://majour.maranatha.edu/index.php/jurnalmanajemen/article/view/1401

Azwar, S. 2012. Reliabilitas dan Validitas. Yogyakarta: Pustaka Pelajar.

Kalie, Moehd Baga. 2004. Bertanam Pepaya. Jakarta : Penebar Swadaya.

Murtini, E.S. dan Qomarudin. 2003. Pengempukan daging dengan Enzim Protease Tanaman Biduri (Calotropis Gigantea). Jurnal Teknol dan Industri Pangan. Vol,XIV,No.3.

Utami, D.P. 2010. Pengaruh Penambahan Ekstrak Buah Nanas (Ananas comosus L. Merr) dan Waktu Pemasakan yang Berbeda Terhadap Kualitas Daging Itik Afkir. Fakultas Pertanian Universitas Sebelas Maret. Surakarta.

Sugiyono. 2010. Metode Penelitian Pendidikan Pendekatan Kuantitatif, kualitatif, dan R\&D. Bandung: Alfabeta.

Sugiyono. 2012. Metode Penelitian Kuantitatif Kualitatif dan R\&D. Bandung: Alfabeta.

Byun, S., Irvin, M. J., Bell, B. A., Irvin, M. J., \& Advanced, B. A. B. (2014). Advanced Math Course Taking: Effects on Math Achievement and College Enrollment. THE JOURNAL OF EXPERIMENTAL EDUCATION, 83(4), 439-468. https://doi.org/10.1080/00220973.2014.919570

Edwards, T. G., \& Chelst, K. R. (2015). Linear Programming in the Classroom Using GeoGebra. Mathematics Teaching, 8(May), 8.

Verhoef, N. C., Coenders, F., Pieters, J. M., van Smaalen, D., \& Tall, D. O. (2015). Professional development through lesson study: teaching the derivative using GeoGebra. Professional Development in Education, 41(1), 109-126. https://doi.org/10.1080/19415257.2014.886285 